\title{
Composition and Subject Structure of Minutes Genre in Religious Style
}

\author{
Tatiana Itskovich, Daria Karmanova, and Natalia Nikolina \\ Ural Federal University named after the first President of Russia B.N. Yeltsin, 620002 Yekateriburg, Russia
}

\begin{abstract}
The article under consideration is devoted to the study of the functioning of the minutes genre in the religious style. The relevance of the research is determined by the fact that in the religious style, minutes is a peripheral genre that functions at the intersection with the official style, therefore it is particularly important to consider the specific features of this genre as a part of a not typical of it religious sphere. The authors examine the peculiarities of the explication of the category of subject and the changes in the category of composition of minutes using the method of the categorical-textual analysis. The research is done with reference to the minutes-books of the Russian Orthodox Church. The examination of the explication of the categories revealed some specificities: the category of subject is expressed through two nomination chains, connected to the logical structure of the statement. The nomination chain related to the agent is characterized by the limited set of additional nominations. The nomination chain related to the predicate is characterized by the variety of lexically new additional nominations. The peculiarity of the category of composition lies in the additional compositional element, reflecting the idea of duality and interaction with the sacred world.
\end{abstract}

\section{Introduction}

The study of the religious style as a part of a paradigm of functional varieties of contemporary Russian literary language is relevant today in modern linguistics. Considering the identification of functional styles relevant to a particular sphere, we should note a paradoxical situation that existed in Russian linguistics: such sphere of public consciousness as religion was not characterised by a particular inherent style as a result of historically formed social interactions that were in Russia in the 20th century. This situation is a fact of the submission of science to ideological principles of those times because the language of religious life as other styles is characterised by a full set of style-forming grounds: a special form of public consciousness and a sphere, a specific goals setting of verbal communication, a set of independent genres-types of texts.

The change of the situation in the former Soviet Union in the 1980's has resulted in the raising of the question about the distinguishing of a separate style, related to religion as a form of the social consciousness. L.P. Krysin supposes that the situation allows for posing the question about the status of this kind of speech: "the religious-predicatory style must be included in the functional stylistic paradigm of the Russian standard language and described in scientific publications on stylistics" [1]

The issue of the singling out of the religious style is not debatable, but at the same time it requires, as some researchers think, a special reservation in spite of the fact that there are grounds that can help to single out the religious style according to the principle of specification and classification of functional styles. So M. N. Kozhina assumes that the fate of the religious style 'on Russian basis' is quite difficult and the grounds for its singling out are limited (a specific bilingualism in the religious field and socio-political reasons of the recent time) that is why the issue of the religious style requires a special focus [2].

However, the scientist marks that nowadays the religious style is broadening its sphere of application. L. P. Krysin, who was the first to pay attention to this problem, raises the question about the specific status of the religious speech, supposing that "the religiouspredicatory style must be included in the functional stylistic paradigm of the Russian standard language and described in scientific publications on stylistics" [1]. He names the corresponding kind of the functional style as religious-predicatory, thereby singling out one of the typical genres-preaching. O. A. Krylova in her turn names this style as church-religious ("The term 'churchreligious' is preferable because it refers to the sphere of social activities where it functions, to the religious sphere of the social consciousness, and to the church leaders as the authors of the corresponding texts. Though such name does not restrict the realisation of this style by the genre of preaching only" [3]). She also thinks that the name 'religious-predicatory' is tautological, it constricts the sphere of the functioning of the style, limiting it by one genre [4].

* Corresponding author: Tatiana.Itckovich@urfu.ru 
We agree with the viewpoint of O. A. Krylova and we should note that the term 'church-religious' she proposes is also tautologic: the concept of the notion 'church' is included in the complex of concepts of the notion 'religion'. Salimovsky who also singles out the 'church-religious' style suggests that we should interpret it from the point of view of a religious consciousness as the latter is represented in religious texts forming its specific features [5]. Noting a developed personal form of religious sphere along with an institutional one, $\mathrm{T}$. $\mathrm{V}$. Matveeva suggests that we should call this style religious [6]. Thus, this researcher comes back to the name of the style that was chosen by a Slovak scholar J. Mistrik [7] in 1922. We agree with this viewpoint and suggests that we should use the term 'religious style' as a reasonable for the indication of a corresponding sphere and a form of public consciousness.

Particular genres descriptions, their systematization, constitutive principle determination are the subject of linguistic study [8-16]. The difficult process of the religious communication is developing in the liturgical and non-liturgical spheres. Canonical genres are functioning and new textual kinds of the liturgical genres, such as prayers, and canons, are being created in the Old Church Slavonic language. The non-liturgical sphere of communication is in its process of developing: confessional newspapers and journals, orthodox TV and radio, internet communication, fiction. Systematization of the religious style genres in terms of field theory results in the determination of nuclear genres related to liturgy properly (prayer, kanoon, akathistos, sermon, etc) and peripheral genres functioning at the intersection of other functional styles (article, essay, charter, minutes, story, novel).

The Russian Orthodox Church today is a complex organisation functioning in different spheres of social life and consciousness that allows for allocation of the following substyles of the religious style: proper religious, official, scientific, publicistic, artistic, and conversational. The relevance of the research under consideration is defined by examination of traditional genres functioning in religious communication.

The official style is required in church as a public institution: baptism, matrimony and divorce certificates are documented; church records are kept: formal letters, invitations, minutes, and charters. The study of two functional styles interaction is carried out with reference to the functioning of particular genres. The subject of research is the minutes genre functioning in the religious style. The authors aim to determine special characteristics of explication of text categories of subject and composition in the minutes genre. The research is based on texts of minutes available on the official website of the Russian Orthodox Church.

\section{Methods of research}

The method of categorical-textual analysis, existing in modern linguistics, consists in studying texts according to their categories. T.V. Matveeva defines textual category as one of interconnected text characteristics, which reflects a particular point of the text by means of language, speech, and composition [17]. Interrelated textual categories can constitute the notion of "text" itself, hence the importance of categorical-textual method of analysis.

A set of the most important text categories can be singled out on the ground of Bühler's psycholinguistic model. Its idea is that the text depends on the three constituents of the act of communication: the speaker, the listener and the subject of speech [18]. So, the categories of subject and composition reflect the subject of speech that determines the choice of such categories for the analysis of minutes as a genre.

\section{Analysis}

Let us proceed to the description of the official style. The official style is one of the functional styles connected to the legal sphere and legal relations among citizens, citizens and government, and different governments. The official style is further divided into the following substyles: legislative, formal, and diplomatic. The genre of minutes is distinguished among the genres of formal substyle [19].

There are various definitions of minutes as a genre. Some of them are focused on the procedural constituent. For example, according to G. A. Kopnina, minutes is a document recording discussions of matters and decision making at meetings, conferences, and proceedings of collective bodies [20]. M. V. Koltunova provides a similar definition, and points out that the minutes are a document containing a consequent accurate record of discussions of matters and decision making at meetings [21]. In this work, we follow the definition given by $\mathrm{T}$. $\mathrm{V}$. Matveeva who defines minutes as an official genre, which aim is to record the discussion of a particular matter and the decision made as a result of the discussion in the written form [22].

Speaking about the extent of research work done on this topic, one should mention that linguists are actively studying the genre of court minutes. Thus, objects of research in the article by L. G. Kirkunova [23] are minutes of witness interview and on-site inspection report. The author clarifies the functions and specific stylistic features of these texts. For instance, an important difference of such texts from others related to the official style is the dialogue nature of written speech: it is crucial to record the interrogated person's words in the form required by law and norms of the Russian language. The article also considers the restricted structure of the interrogation report.

L. M. Mesropyan [24] also talks about the specific structure of minutes of an interrogation in her article "Linguistic Expertise of the Interrogation Records: Speech Identification of Interrogatee as the Means of Identifying the Proceedings Defects". In addition, the author also mentions possible distortions of an interrogatee's speech and, consequently, issues connected with the attribution of such texts and inspection. 
In her article, E. E. Abramkina [25] examines the problem of authorship and boundaries of genre and individual author's traits mentioning stylistic and genre specific aspects of interrogation report as the secondary genre related to the interrogation genre (oral speech).

Concerning the previous study of official substyle of the religious functional style, it is to be noted that minutes of the religious style have not been considered previously as a subject of study. However, there are works devoted to the analysis of other official genres, for example, the analysis of monastery statutes [26].

Speaking about the structure and general characteristic of the category of subject, it should be specially noted that "the subject of the text is the subjectmatter of the whole text; its informative nucleus underlying the author's intention" [17] expressed by thematic groups that make thematic field. The subjectmatter can be denoted by several nominations, therefore it is important to single out a nomination chain, i.e. a list of denotations of a particular subject-matter for analyzing the category of subject. There are two types of nomination chains: main and additional. The main nomination chain contains the name of the whole text and can include some basic and additional units [18].

We will deal with the explication of the category of subject in minutes functioning in the religious style. The main subject of the text is represented in the recitals HAVING HEARD which is an obligatory composition element of minutes. For instance, in minute-book 98 such subject is the visit of Patriarch Kirill of Moscow to Romania on October 26-28, 2017. The subject is represented in the text by two nomination chains reflecting the agent - His Holiness Kirill, Patriarch of Moscow and All Russia - and the predicate - visit.

Let us consider the first nomination line reflecting the agent. A nomination that opens a chain is called the first nomination [18]. In the text under consideration such nomination is His Holiness Kirill, Patriarch of Moscow and All Russia that takes place in the strong position of the text, recitals HAVING HEARD. This nomination is a detailed phrase of a describing character and the name of the official post of the Primate of the Russian Orthodox Church. It appears in the minutes twice: at the beginning of the text and in the middle of the expletive element of minutes REFERENCE.

Complex syntactic structure is a peculiarity of this nomination: the agent is the name Kirill and the predicate is the occupation Patriarch. There is a combination of pre- (Svyatejshij Patriarh - His Holiness Patriarch) and postposition (Patriarh Moskovskij i vseya Rusi - Patriarch of Moscow and All Russia) of the adjectives with the noun as the main word in the predicate group.

Therewith the definitions in the preposition are of a hierarchic character, i.e. they define an ecclesiastical status of a predicate: His Holiness, His Beatitude; Blazhennejshij Patriarh Rumynskij Daniil (His Beatitude Daniel, Patriarch of All Romania), Blazhennejshij arhiepiskop Tiranskij i vsej Albanii Anastasij (His Beatitude, Anastasios, Archbishop of Tirana, Durrës and All Albania), Svyatejshij Patriarh Kirill (His Holiness, Kirill, Patriarch).
A prepositional adjective can be omitted in the case of a lower position of the agent: Metropolitan Naum of Ruse, Archbishop Jakub of Bialystok-Gdansk. It is comparable to the nomination of official occupations in secular society, which also do not have a prepositional element: the governor of the Sverdlovsk region E. Kuyvashev, The President of the Russian Federation V. Putin.

Postpositional part is a toponymical adjective that reflects the territorial belonging of a predicate, e.g. Patriarch of Moscow, Bishop of Nikorzminda. Such type of phrases characterises the post titles in official structures of the church: His Beatitude Daniel, Patriarch of All Romania; His Beatitude Anastasios, Archbishop of Tirana, Durrës and all Albania; His Beatitude Rastislav, Metropolitan of Czech Lands and Slovakia

Primary nomination is also a basic nomination because it reflects the official nomination of church office. Basic nomination is a nomination which can be an identifier in relation to all the nominations of the chain [18].

The most frequent unit of the nomination chain that T.V. Matveeva defines as the main is His Holiness Kirill, Patriarch. It is used in the text four times in the compositionally important parts of the minutes: at the beginning of each minor subject, reflecting the actions of the predicate: His Holiness Patriarch Kirill was accompanied by a delegation; fraternal meeting between His Holiness Patriarch Kirill and His Beatitude Patriarch Daniel; His Holiness Patriarch Kirill addressed to believers with the sermon; His Holiness Patriarch Kirill took part in the session of Holy Synod of the Romanian Orthodox Church. It should be noted that the main nomination is fragmentarily mentioned throughout the whole text, keeping its semantic cohesion.

There is a wide range of additional nominations related to the basic nomination in the document. Substitutes are represented by the personal pronoun him in the concluding part BE IT RESOLVED: to express heartfelt thanks to His Beatitude Daniel, Patriarch of All Romania for his warm hospitality expressed to the Primate of the Russian Orthodox Church and the delegation that accompanied him.

Transformations: the main nomination His Holiness Kirill, Patriarch (Svyatejshij Patriarh Kirill) is the contracted transformation of the basic nomination His Holiness Kirill, Patriarch of Moscow and all Russia. It is also used as the grammatical transformation Svyatejshego Patriarha Kirilla.

Other additional nominations belong to the group of lexically new referential identical nominations: Primate of the Russian Orthodox Church (2 times), His Holiness (1 time).

For constructing the nomination chain we should accept the following notations: the primary and basic nomination His Holiness Kirill, Patriarch of Moscow and all Russia - a, the main nomination-transformation His Holiness Kirill, Patriarch - b, referential-identical Primate of the Russian Orthodox Church - c, referentialidentical His Holiness $-\mathrm{d}$, the substitute him - e.

Nomination chain analysis shows that the representation of the basic nomination (a) is intensive in 
the first part of the text (3). The main nomination (b) is represented regularly in the whole text (4). In the second part of the text, referential identical nominations appear (c, d). The usage of substitutes is not typical of the nomination chain: there is only one instance at the end of the text. The absence of synonymous and taxonomic units is also to be noted.

The analysis of the texts of minutes shows the typical traits for the official style, such as: exactness and frequency of use of the nominations, reflecting the hierarchical status of the agent.

Subject duality is a feature of the religious functional style. There are two subjects: one reflects the real world and the other reflects the sacred world [13]. We can observe an explication of the subject in the secular aspect: it reflects human's actions in the real world. There is a single explication of the sacred subject in the concluding part only, at the last point. It is an appeal to the sacred world: to praise God for the accomplished concelebration and fraternal communication with the Primates and the representatives of Local Orthodox Churches on church celebrations in Bucharest.

Let us consider the minutes in order to identify the nomination chain connected with the predicate: the text is dedicated to Patriarch Kirill's visit. The peculiarity of the chain is the reflection of the real events that took place during the visit according to its programme.

The primary basic nomination is visit (a). The main nomination which is distinguished on the principle of frequency is also an additional nomination in relation to the basic nomination meeting (b). Additional nominations are a synonym trip (c), the words constituting on logical grounds a subject field: donation (d), Divine liturgy (e), reading the Gospel (f), sermon $(\mathrm{g})$, concert $(\mathrm{h})$, prayer service $(\mathrm{i})$, session $(\mathrm{j})$, speech $(\mathrm{k})$, hospitality (l), concelebration (m), fraternal communication (n). There are no transformations or substitutes. The visit in accordance with the programme of stay consisted of certain events, whose lexical designation constitutes the nomination chain. The subject chain is as follows: a-b-c-d-e-f-g-h-i-j-k-l-m-no.

Fragmentation of the subject visit into the minor subjects is expressed through the diversity of lexicallynew contextual taxonomic units without other types of nomination.

The minutes genre follows a rigid structure and is full of clichés. We will further consider the peculiarities of compositional division of the traditional minutes genre. Speaking about the structure of minutes, T. V. Matveeva distinguishes two compositional parts: the recitals and the concluding part. "The recitals is formed according to the formula HAVING HEARD [what], the concluding part is formed according to the formula $\mathrm{BE}$ IT RESOLVED [result]" [22].

According to the comprehensiveness of the course of meetings, G.A. Kopnina singles out the full and the short types of minutes. The difference between them is in the set of obligatory and additional elements of the composition, characterising each type of minutes. The short minutes contains only obligatory elements of the composition, such as the questions of a discussion and the decisions taken. The full minutes contains additional elements of the composition: reference details, the introductory part, and the main part. The introductory part consists of the permanent information ("the Chairman", "the secretary", "attendees") and variable information that is surnames and initials of the members of the meeting. The main part consists of the sections, constructed according to the following scheme: "having heard", "speakers", "taken the decision" [20].

\section{Conclusion}

The analysis of texts of minutes functioning in the religious functional style shows the peculiarities of the category of subject explication. The peculiarities are as follows: there are two nomination chains connected with the nomination of the agent and the nomination of the predicate. The first nomination chain connected with the agent is represented by a limited set of additional nominations among which reduced transforms are used. Referential identical nominations are represented minimally. Substitutes are almost never used. The second nomination chain connected with the predicate is based on a variety of additional lexically new nominations reflecting contextual taxonomic relations. The category of composition analysis shows that the structure is preserved even with its functioning in a fundamentally different sphere - religious. However, an optional point reflecting the idea of duality and interaction with the sacred world is added to the part BE IT RESOLVED, which is typical only of the religious functional style.

Supported by Act 211 of Government of the Russian Federation, agreement № 02.A03.21.0006.

The reported study was funded by RFBR according to research project №18-012-00382 A.

\section{References}

1. L. P. Krysin. Coll. of articles 'Poetics. Stylistics. Language and culture', 135-138 (1996)

2. M. N. Kozhina. Stylistic encyclopedic dictionary of the Russian language (BRE, Moscow, 2003)

3. O. A. Krylova. Proceedings of the Conference 'Russian language in Russia at the turn of the 20th century' (2003)

4. O. A. Krylova. Linguistic stylistics. (Moscow, Vysshaya Shkola, 2008)

5. L. R. Duskaleva, M. N. Kozhina, V. A. Salimovskij. Russian language stylistics (Flinta, Moscow, 2008)

6. N.A. Kupina, T.V. Matveeva. Stylistics of modern Russian language, (Jurajt Publ., Moscow, 2013)

7. J. Mistrik. Stylistyka 1, 82-89 (1992)

8. M. Voytak, Text: stereotype and creativity 1, 214230 (1998)

9. M. Voytak, Stereotype and creativity in a text: interuniversity collection of scientific works, 5, 270-285 (2002) 
10. M. Voytak, Stereotypes and creativity in a text: interuniversity collection of scientific works, 6, 323338 (2003)

11. A. K. Gadomsky, Scientific notes of the Taurian national university of V.I. Vernadsky. Philology series, 19 (58), 186-192 (2006)

12. A. K. Gadomsky, The black sea region Culture, 137, 89-92 (2008)

13. T. V. Itskovich, The genre system of religious style on the communicative-pragmatic and categoricaltext reason. (Dr. philol. sci. thesis diss., Ekaterinburg, 2016)

14. O. A. Prohvatilova, Orthodox sermon and prayer as a phenomenon of modern-sounding speech, (VolSU Publish., Volgograd, 1999)

15. O. A. Prohvatilova, Proceedings of Nizhny Novgorod seminary, 5, 349-368, (2007)

16. V. A. Salimovskiy, K. S. Suslova, Speech genres: collection of scientific works, 4, 280-292 (2005)

17. T. V. Matveeva, Learner Dictionary: Russian language, speech culture, style, rhetoric (Moscow: Flinta; Nauka. 2003)

18. T.V. Matveeva, Functional styles in an aspect of text categories (Ural, Sverdlovsk, 1990)

19. T. A. Zueva, E. N. Ivanova, The strategies of creative editing (Direct Media, Moscow-Berlin, 2015)

20. G. A. Kopnina, L. Ju. Ivanov, A.P. Skovorodnikov, Shirjaev E.N. Minutes, Culture of russian speech: an encyclopaedic glossary, (Flinta; Nauka, Moscow, 2003)

21. M. V. Koltunova, Language and business communication: Guides, rhetoric, etiquette. Study guide, (Economics, Moscow, 2000)

22. T. V. Matveeva, Complete dictionary of linguistic terms (Fenix, Rostov-na-Donu, 2010)

23. L. G. Kyrkunova, Stereotype and creativity in a text: interuniversity collection of scientific works, 7, 290311 (2004)

24. L. M. Mesropyan, Verbal procedural acts. The collection of articles with the reference to allrussian round-table conference, (The Russian Academy of Justice. Northwest branch. 2017)

25. E. E. Abramkina, Tomsk State University Journal, 415, 158-163 (2017)

26. V. A. Mishlanov, E. S. Khudyakova, Philological notes, 14, (2008) 